\title{
АС БЕРУ ЖӘНЕ ТАС МУСІН (жік түскен дәстүрлер)
}

\section{Орынбай Жаңабайұлы Ошанов ${ }^{1}$}

\author{
${ }_{1}$ «Ұлы даланы зерттеу институты» ЖШС, Алматы қ., Қазақстан. \\ E-mail:dadan_@mail.ru
}

\begin{abstract}
Аннотация. Мақалада қазақтың ас беру дәстүрі мен тас мүсіннің ерте замандарда бір ғұрыптық шара болғандығы қарастырылып жан-жақты дәлелденеді. Тас мүсін тұрған жерлердің қазақтың ас берген «ошақ» орындарымен қатар келуі екі ғұрыптың бастауы бір екендігін көрсетеді. Далалық зерттеу барысында Қарағанды облысының Ақтоғай ауданы жерінде анықталған «Орманбет ошағы», «Ербекей ошағы», «Шегетай ошағы» орындары және осы алқапта орналасқан тас мүсіндер дәлелге келтіріледі. Мақалада экспедициялық жұмыстардың нәтижесі және ас беру барысында орын алатын салт-дәстүрлер және көне ғұрыптар сөз болады.Тас мүсіннің бойындағы «ыдыс», «аяқ-табақ» секілді дүниелер осы көне ас беру ғұрпымен байланысты туындағаны және т.б. жайттар қарастырылады. Ас беру ғұрпының қоғамдық ролі, тарихи-саяси маңызы анықталады. Мақалада қазақпен қатар қырғыз халқындағы ас беру дәстүрі қоса сипатталады.
\end{abstract}

Түйін сөздер: ас, ошақ, сауын айту, жөнелту, тас мүсін, құрбандық орын, тұл ат, бәйге, этнография, археология

\section{ТРИЗНА И КАМЕННЫЕ ИЗВАЯНИЯ (разделенная традиция)}

\section{Орынбай Жанабайулы Ошанов ${ }^{1}$}

${ }^{1}$ TОО «Институт исследования Великой степи», г. Алматы, Қазақстан. E-mail: dadan_@mail.ru

Аннотация. В статье всесторонне рассматривается и обосновывается идея о том, что казахская традиция проведения тризн (ас беру) и установка каменных изваяний в ранний период представляли собой одно обрядовое действие. На это указывает то, что места установки каменных изваяний совпадают с местами проведения тризн последних веков. Эти места в степи встречаются в виде отдельных топонимов. Как обычно в народной памяти эти долины до сих пор ассоциируются с поминками и называются в честь того или иного усопшего - «очаг такого-то» (напр.: «Очаг Орманбета», «очаг Бектаса» и т.д.). Очаг - это то место, где во время поминок распологались «полевые» кухни, там же проводился убой домашних животных, ставились казаны и бесперестанно варилось мясо для гостей. В степи в некоторых местах до сих пор сохранились следы очага в виде лунки или места, обложенные камнем. В статье так же приводятся результаты полевых исследований соответствующих мест; обобщены традиции и древние ритуалы, сопровождавшие тризну; рассмотрены элементы каменных изваяний 
с изображением посуды и утвари, свидетельствующие об их связи с древней традицией тризн, раскрывается их семантическое значение.

Ключевые слова: тризна, поминки, «сауын айту» (приглашение), проводы, очаг, изваяния, жертвенник, жертвенный конь, скачки, этнография, археология

\title{
TRIZNAAND STONE SCULPTURES
}

(tradition divided)

\author{
Orynbay Zh. Oshanov ${ }^{1}$ \\ ${ }^{1}$ LLP «Institute for research of the Great steppe», Almaty, Kazakhstan. \\ E-mail:dadan_@mail.ru
}

\begin{abstract}
The article comprehensively examines and substantiates the idea that the Kazakh tradition of triznas (as beru) and the installation of stone statues in the early period were one ritual action. This is indicated by the fact that the places where the stone statues were installed coincide with the places where the funeral triznas of the last centuries were held. People's memory of these places is still associated with commemoration, and calls the honor of the deceased - "the hearth of such" (e.g.: "the hearth of Ormanbet", "the hearth of Bektas", etc.). The hearth is the place where during the commemoration "field" kitchens were arranged, the cattle allocated for slaughter were slaughtered there, and kazans were set up, and meat was continuously cooked for the guests. The article also contains the results of expeditionary studies of the relevant places; summarized the traditions and ancient rituals that accompanied the funeral feast; elements of stone statues with the image of dishes and utensils were considered, testifying to their connection with the ancient tradition of triznas, and their semantic meaning is revealed.
\end{abstract}

Keywords: trizna, commemoration, farewell, hearth, statues, altar, sacrificial horse, horse racing, ethnography, archaeology

\section{Kipicne}

Тас мүсіндердің мән-мағынасын анықтауда археологиямен қатар жазба және этнографиялық деректерді ұштастыра зерттеудің маңызды екенін кезінде Л. Р. Кызласов атап көрсеткен болатын [Кызласов, 1964, с. 27]. Сонымен қатар С. И. Руденко Пазырық обаларының тұрғызылуы ас секілді шаралар негізінде іске асқанын алға тартып, археология мәселесінде қазақ, қырғыз халықтарының этнографиясын ден қойып зерттеудің маңыздылығын жазады [Руденко, 1953, с. 256-257]. Өкінішке орай бұл мәселеде (жалпы археологияда) түркімоңғол халықтарының рухани және заттық мәдениетіне әлі күнге жете мән бермейміз. Ал бұл халықтардың заттық және рухани мұраларында далада тұрған тарихи ескерткіштердің көптеген шешуші кілті жатыр.

Зерттеушілердің назарынан тыс қалып келе жатқан әдет-ғұрыптардың бірі (С. И. Руденко нұсқағандай) ac беру дәстүрі. Зерттеп қарасаңыз ac беру дәстүрінің далада тұрған тас мүсіндермен тамырластығы байқалады. Тас мүсін тұрғызу ерте дәуірлерде ас беру дәстүрінің негізгі ғұрыптық шараларының бірі екендігін болжауға болады. Тек тастан мүсін тұрғызу ғасырлар қойнауында қалып, ал ас берудің басқа ғұрыптары XX ғ. бас кезіне дейін сақталып жетті. 
Халық жадында сақталған көне астың бірі - атақты Едігенің асы (XV ғ.). Ұлытауда Едігенің тауының етегінде «Едігенің майлы жұрты» деген алқап бар. Халық арасындағы аңыз бойынша Едігенің асында сойылған малдың етінен бұлақтың суы май болып ағыпты. Содан осы су «Майбұлақ» атанып кеткен (I). Асқа сойылған атының бассүйегін моласының басына қойған. Бассүйек таудың басында «соғыстан кейінгі уақытқа дейін болды» (1941-1945 жж.) дейді көзімен көрген Рашид ақсақал (II).

\section{Материалдын сипаттамасы}

Түсінікті болуы үшін алдымен ac беру дәстүріне, және оның барысында орын алатын көне далалық ғұрыптарға тоқтала кетсек.

Дәстүрлі ас беру түрі XX ғ. бас кезіне дейін қазақ пен қырғыз халқында сақталып келді. Ас - адам қайтыс болғаннан күннен кезек алатын (қонағасы, жетісі, қырқы, жүзі) ғұрыптық шаралардың жылдық нүктесі. Өз тілімен айтқанда жөнелтудің соңы. Дегенмен, белгілі бір рудың ішінен шыққан атақты адамына немесе тұтас бір рудың бастауында тұрған тұлғаларға ас беру салты араға жылдар салып барып тұрақты түрде қайталанып отырады. Мысалы, С. Шәріповтің жазуынша XIX ғ. өмір сүрген Ерден Сандыбайұлына үш рет ас берілген [Шарипов, 1982, 296-б.]. Қазақ халқы XVIII ғ. өмір сүрген атақты би-батырларға және одан да ерте ру бастауында тұрған түп бабаларға әлі күнге (сол ру өкілдері) ac беріп келеді. Әсіресе Қазақстан тәуелсізідік алуымен бұл үрдіс заманауи көріністермен, жаңаша белең алды.

Асты кез-келген адам бере алмайды. Ол мол шығынды қажет ететін шаралардың бірі. Сондықтан асты дәулеті жеткен адамдар береді. Кей жағдайда белгілі адамы қайтыс болғанда намыс үшін сол рудың өкілдері ас шығынын жабылып көтеріп алған оқиғаларда бар. Ал хан, сұлтандардың асының шығыны қашанда қоластындағы рудың мойнына жүктелген. Асқа үш жүз өкілдері ғана емес, іргелес халықтардың (қалмақ, қырғыз) келіп қатысқаны жайлы ауыз әдебиеті мұралары жетерлік.

Назар аударарлық жайт қазақ халқы арасында ас өткен жерлер өз алдына топоним ретінде «ошақ» атауымен сақталып келеді. Мысалға «Ботақан ошағы» (Шыңғыстау), Бектастың ошағы (Торғай), «Ерденнің ошағы» (Ұлытау), «Шегірдің ошағы» (Ұлытау), «Орманбеттің ошағы», «Ербекей ошағы», «Шегетайдың ошағы» (соңғы үшеуі Қарағанды обл. Ақтоғай ауд.) деген секілді атаулармен әлі күнге далада кездесе береді. Яғни бұл жерлер ас арналған марқұмның есімімен аталып қалған. «Ошақ» деп ас кезінде ошақ құрылып, қазан асылған жерлерді айтады. Ерденге ас берілген жерде (Ұлытауда) әлі күнге ошақтың орындары сақталған.

Әдетте ошақтар өзеннің бойында орналасады. Астың бірінші күні «Ошақ құрар» деп аталады. Бұл күні ас беретін жақтың адамдары келіп ошақ құрып, үй тігу секілді жұмыстары басталады. Ал асқа келуші қонақтар үшін киіз үйлер ошақ құрылған жерден алыстау, көбіне тау бөктерлей немесе жазық алқап ортасында өз алдына бөлек тігілген. Ортасында марқұмның қаралы туы тігілген киіз үйі орналасады. Киіз үй ішінде марқұмның тұтынған заттарын (киімі, ертоқымы, қамшысы, қару-жарағы) іліп қояды. И. А. Кастанье бұндай көріністі «тұлдап қойды» деп айтатынын жеткізеді [Кастанье, 1911, с. 91]. 
Қонақтар ас барысында осы үйге келіп бата қайырып, дұға оқыған.

Асқа шақырылған адамдардың санына немесе ас беруші адамдардың әл-ауқатына байланысты 200-300 үй, кейде одан да көп киіз үй тігілетін болған. Жазба деректердің өзінде 1000 киіз үйге дейін тігілгені жайлы мәліметтер кездеседі [Народы России, 1880 , с. 52]. Бұл деректе асқа келген адамдар саны 15 мыңға дейін жететіні жазылған [Народы России, 1880, с. 51]. Халық аузында Ағыбай батырдың асында жиналған халықтың саны 20 мыңға дейін жетті деген мәліметтер айтылады. Ас ауқымына байланысты 3-күн, тіпті кейбір ұлы астар 7 күнге дейін созылған.

Қаралы ту тігілген үйде жоқтау айтылып, жылау секілді рәсімдер орындалғанымен, жалпы астың негізгі барысы ойын-сауық түрінде өтеді. Астың өту барысын жиналған рудың арасындағы өзара бәсеке деп қарастыруға болады. Өйткені мұнда әр рудың намысылн жыртқан ақындар айтысы, балуандар күресі, найзагерлер сайысы, ат жарысы және т.б. ойын-шаралар өтеді. Асқа барар ру «ат апарамыз ба, ақын апарамыз ба?!» деп өз ішіндегі таңдаулы ақыны мен жүйрігін сайлап алатын болған. Бұдан бөлек күреске түсер балуаны, бір қойдың (кейде тайдың) етін жейтін «мешкейі» қоса жүреді.

Ac берген жақтың шығыны ерекше болады. Үлкен астарда 150-ден 300-ге дейін жылқы, 500 қой сойылып, келген қонақтарға тартылған. Мысалы 1874 ж. Лабақ Куат баласының асына 300 жылқы, 500 қой; 1913 ж. Сүгірұлына 260 жылқы, 300 қой жұмсалған [Шарипов, 1982, 296-б.]. Бұл тек сойыс мальныңң шығыны. Ал, ат жарысының жүлдесі одан неше есе асып түседі. Жазба деректердің өзінде XIX ғ. кейбір астарда ат жа- рысында алғашқы 15 атқа жүлде тағайындалғаны кездеседі. Алдымен келген жүйріктің өзіне берілер сыйлық 100 рубльдің товары, 30 түйе, 100 жылқы, 30 сиыр, 500 қой болған [Народы России, 1880, с. 55]. Тіпті одан да көп, әрі қымбат сыйлықтар таратылғаны аталады. Сыйлықтың басына ат жетектеген бір құл мен бір күннің қоса берілетіні аңыз-әңгімелер мен жазба деректерде жиі көрініс береді [Чорманов, 2000, с. 23].

Ас соңында жыл бойы тұрған cen бұзылады. Киімдері жақын адамдарының арасында таратылады. Егер қайтқан адам жауынгер болса, оның сауыт сайманы өзінің аманаты бойынша беріледі. Мысалы белгілі Көтібар батыр өлер алдында өзінің наркескен қылышы мен жүйрік атының жабуын ас кезінде аты бәйгеден келген адамға («ерекке») беруін аманаттаған. Осы аста шұбыртпалы Ағыбай батырдың аты бірінші болып келіп, ол бас жүлдеден бөлек Көтібар батырдың наркескен қылышы мен ат жабуын иемденген [Ақжолтай Ағыбай, 1992, 96 б.]. Ағыбай Кенесары ханның бас батыры болған. Ол Кенесары хан көтерілісінің (1837-1847 жж.) басынан аяғына дейін қатысқан тарихи тұлға. Қазақтардың дүниеден озған адамының сауытсайманын бәйгеге тігу дәстүрі жайлы Н. Рычков өзінің күнделік жазбаларында келтіреді [Дневные записки, 1772, с. 28].

Жазба деректерден XIX ғ. бас кезінде қазақтарда қайтыс болған адамның «бейнесін» жасау дәстүрі сақталғанын кездестіруге болады. Бұл деректе киіз үй ішінде ас өткенге дейін қара тумен бірге марқұмды бейнелейтін мүсін қойылатыны жазылған. Мысалы: «По окончании похорон вывешивают у юрты на длинном шесте небольшой лоскут черного 
бархата или плису, вырезанный треугольником, а внутри юрты ставять болвана, наряженного в лучшее платье и имеющего сверх оного панцирь или кольчугу, а на голове шлем. Пред сим болваном мать, жены и дочери покойного, кроме мужчин, каждое утро и вечер при захождении солнца, стоя на коленах оплакивают покойника, воспоминая и выхваляя добродетели его, храбрость, рукоделия и домовитость» [Киргиз-кайсаки, 1820, с. 162-163].

Бұндай «қуыршаққа» марқұмның киімін кигізіп жоқтау айту жайлы А. Левшин де жазады. Әрі бұл дәстүрдің Орта жүздің кейбір жерлерінде сақталғанына тоқталады [Левшин, 1832, с. 110]. Өзінің зерттеу мақаласында Л. Қызыласовта бұл дәстүрдің ескі дәуірлерде қазақпен бірге қырғыз, якут халықтарында болғанына тоқталады [Кызыласов, 1964, c. 38].

Марқұмның дүниеден озғаннан кейін орын алатын келесідей ғұрыптық рәсімдері болады:

Қараль ту. Қайтқан адамның үйінде асы өткенше тігіліп тұратын туды айтады. Бұны «қара тұрғызу» деп атаған [Халид, 1992, 180-б.]. Қара деген атауы қайғыны бейнелейтіндіктен, әрі білдіретіндіктен айтылады. Әйтпесе қайтқан адамның барлығына қара түсті ту тігіле бермейді. Мысалы бір деректе ер адамға ақ ту, әйел адамға қара ту тігеді деп жазылады [Народы России, 1880, с. 50]. Ал Құрбанғали Халид жас адамға қызыл түс, ересек адамға ақ түс, орта жастағы адам болса бір жағы ақ, бір жағы қара қылып ту тіккенін жазады [1992, 180-б.]. И. А. Кастаньенің дерегі де осыған үндес келеді. Ол жас адам қайтыс болса найзаның ұшына қызыл лента байланатынын келтіреді [Кастанье, 1911, с. 71]. Қ. Халидтің жазуынша төре тұқымы қайтыс болса, тірі кезінде ұстаған тулары тігілетін болған [1992, 180-б.]. Қаралы ту тіккен үй ас кезінде ортада орналасады. Асқа келген адамдар осы үйге бас сұғып бата жасап шығады. Қаралы туды ас аяқталғаннан кейін ақсақалға немесе сыйлы адамға сындыртатын болған. Бұл рәсім кезінде әйел адамдар жоқтау айтып, жылап-сықтап дауыс шығарады. Қаралы туды сындырумен аза тұту аяқталады.

Сиректе болса қазақ пен қырғыз халықтарының ас беру дәстүрінде көрініс беретін «түйе шешу» («тайлақ тарту», «жез бұйдалы қара інген») ғұрыптық ойыны бар. Ә. Марғұлан бұл ойынға мән беріп ерте дәуірлерден сақталып қалған ойын екенін жазады [1985, 279-б]. Р. Шомбал-Кукашев бұл ғұрыптық ойынның мән-мағынасын терең зерделей келе оның қаралы туды сындырумен мағаналас деп қорытқан [2001].

Жыртыс. Негізі жыртыс адам қайтыс болған кезден бастап азаға қатысқан адамдарға, көңіл айтып келушілерге үлестірілетін мата түрлері. Ол үшін арнайы тең-тең маталар сатып алынады. «Жыртыс» үшін алынатын маталардың шығыны да үлкен. Көңіл айта келген адамның барлығына «тәбәрік» деп кездемеден бастап, ұзындығы 2 м кем емес мата үлестіріледі. Аста жыртыс берілмейді. Бірақ теңделген мата түрлері аста бәйге тіккен сыйлықтардың ішінен орын алады. Мысалы деректе: «Бывают и такие байги, на которых первый приз состоит из 100 верблюдов, 100 лошадей, 100 коров, 100 баранов, 100 рублей, 100 коканов, 100 аршин сукна, 100 аршин шай (канауса) и 100 концов маты» деп келеді [Народы России, 1880, с. 54-55]. Соңғы үшеуі мата түрлеріне жатады. Бұл жыртысқа кететін шығынның ас иесі үшін оңғайға түспейтінін аңғаруға болады. 
Сеп жинау. Бұл марқұмның тірі кезінде пайдаланған дүниесін жинап қою. Асына дейін сақталады.

Cen бұзу. Ас аяқталғаннан кейін орындалатын рәсім. Жиналған септі бір адамға арнайы бұздырады. Сеп бұзған адамға ат-шапан сыйлық беріледі [Халид, 1992, 183-б.]

Тұл ат. Тұл ат марқұмның тірі кезінде мінген аты болып табылады. Тұл аттың ғұрыптық жағы басым. Иесі қайтыс болғаннан кейін аты тұлданып (құйрығы кесіледі) асқа дейін құр жіберіледі. Тек көш кезінде ғана ұсталынып, ерттеледі. Иесінің тұтынған ер-тұрманын салады. Тек ертоқым керісінше (алды артына қаратылады) ерттеліп, үстіне иесінің киімін жауып, ердің қасына бас киімін кигізіп, көшпен бірге алып жүреді [Кастанье, 1911, с. 89]. Жауынгер адам болса ертоқымға қару-жарағы асылады. Бұндай көшті «қ̧аральл көш» деп атаған. И. А. Кастаньенің жазуынша әйел адам қайтыс болса, оның ертоқымын түйеге салып, үстіне киімін және орамалын асып қояды. Түйенің бұйдасын қызы, ол болмаған жағдайда келіні жетекке алатыны туралы маңызды мәліметтер келтіреді [Кастанье, 1911, с. 71].

Тұл атты астың соңғы күні шалады. Шалар алдында жоқтау айтылады. Оның еті асқа жиналған халықтың ішіндегі ерекше сыйлы қонақтарға беріледі. Тұл аттың бас сүйегін моланың басына қойатын болған.

Тұл қзатылн. Бұл атау қазақтың арасында сақталып келе жатқан көне сөздердің бірі. XIX ғ. екінші жартысы және XX ғ. бас кезінде өмір сүрген Қ. Халид «тұл қатын» жайлы «ері жоқ еркімен кеткен әйел» деп түсінік берген [Халид, 1992, 180-б.]. Әдетте күйеуі өлген әйелді «жесір» дейді. Әрі салт бойынша қазақ қоғамында күйеуі өлген әйел жылы өтіп, асы берілгеннен кейін әмеңгерлік салт бойынша күйеуінің туыстарының біріне тұрмысқа шығады. Яғни, жесір әйел мен тұл қатынды шатастыруға болмайды.

Егер жоғарыда келтірілген тұл аттың атқарушы маңызын ескерсек, онда ерте дәуірлерде (сақ, түркі кезеңдерінде) «тұл қатын» жесір әйелдерден бөлектеніп күйеуінің соңынан о дүниеге аттандырылатын «құрбандық» болуы керек. Көне қытай жылнамаларында үйсін тайпасының билеушісіне ұзатылған император қызының осы салтқа тап келгені туралы мәліметтер сақталған. Тек ол өз елінде бұндай салттың жоғын айтып, зорға басын аман алып қалады. Бұл жайтқа қарағанда «тұл қатын» басқа елден келген (жорық кезінде олжаға келген) әйелдерінің ішінен, әлі балалы болмағаны таңдалатын секілді. С. И. Руденко бұл жөнінде: «Быть может, это были младшие жены, взятые из другого племени в “знак мира и родства"» деп жазады [Руденко, 1953, c. 254].

Сірә, уақыт өте келе бұл салт қолданыстан шыққаннан кейін, сол ескі дәуірлерден сарқыншақ ретінде ауыз-екі сөзде «тұл қатын» аты ғана сақталып жеткен. Қ. Халидтің тұл қатынды «еркімен кеткен әйел» деп сипаттауына қарағанда, кейін бұндай әйелді бостандыққа қойа беруден келіп шықса керек. Соған қарағанда тұл қатынға әмеңгерлік салты жүрмейді, таңдауы өз еркінде.

Қазақта «Тұл қатын» деген жұлдызатауы бар. Олхалықтүсінігінде «қыдырма жұлдыз» қатарына жатады. «Тұл қатын» жұлдызы кей жылдары күн батқан соң, іле шақырайып батыстан көрінеді. Кейде аспан төрінде көрінбей кетеді. Ол шығыстан таң алдында көрінбеген жылы батыстан туады. Әрі күн сайын (шығысқа қарай) 
өрлей береді. Сондықтан халық тұлқатын жұлдызын «қыдырма» деп атаған [Әбішев, 1962, 42-б.]. Бұл жұлдыздың сипатынан Қ. Халидтің тұл қатынды «өз еркімен кеткен әйел» сипатымен үндес келетінін аңғаруға болады.

Әрине «тұл қатын» дәстүрі қоғамның барлық өкілдеріне тән емес. Ол тек ақсүйектерге, дәулеті жеткен адамдарға тән көрініс екені анық. Қарапайым адам өз басы ғана жерленіп, қасына пышағы мен малдың бір мүшесі ғана қойылады. Оның асы да қарапайым өтеді (ырымы жасалады).

«Ат жетектеген құл мен күнз». Қазақ астарында тағы бір көне рәсім бар. Ол кейбір астарда ат жарысында бірінші келген жүлдеге «ат жетектеген күң мен құлдың» қоса берілуі. Бұл рәсімде сонау сақ-түрік дәуірлерінде орын алатын құрбандықтардың сарқыншағы болуы тиіс, яғни заманына қарай өзгеріске ұшыраған дәстүр деген ой туындайды. Өйткені қайтыс болған күйеуінің соңынан әйелінен бөлек, қызметші құлдары мен күндері қоса аттандырылатыны белгілі.

Жалпы қоғам дамыған сайын гуманизмдік (адамгершілік) сипаты бел алады. Сол сияқты түркі-моңғол халықтары да ғасырлар өткен сайын көптеген архаикалық дәстүрлерден арыла бастайды, әрі заманына қарай оның жаңаша бейімделген түрлеріне өтеді. Бұл әсер етуші себептердің қатарында бірінші кезекте діни фактор басты орынды иеленетіні анық. Сондықтан бір кезде о дүниеге аттандырылған қызметшілер, заман өте келе тіріқалдырылып, бәйгеден келген аттың жүлдесінің ішінде көрініс тапқан деп тұжырымдауға болады.

«Ат жетектеген күң» деген атауы болмаса, шын мәнінде күнді ұзатылған қыз секілді киіндіріп, ерттеулі аттың үстіне отырғызып беретін болған. Бәйге болатын күні бұл «жүлделер» көпшіліктің көзіне көрсетіліп, жеке жерге «көрмеге» қойылған. Бәйге аттар келгенше күң аттың үстінде, күннің астында күтіп отыруға мәжбүр болады. Осындай бір көріністі қазақтардың асында өз көзімен көрген В. Радлов былайша сипаттап жазады: «Для победителей скачек было предназначено десять призов. Первым была небольшая юрта, крытая красным сукном, со всей необходимой домашней утварью. Перед ней на оседланной лошади сидела девушка в костюме невесты, на ее голове - саукеле. Кроме того, около юрты находилось пятьдесят голов разного домашнего скота (верблюды, лошади, коровы и овцы). Второй приз составляли десять ямбов серебра и по десять голов каждого скота и т.д.» [Радлов, 1989, с. 317]. Бәйгеге құл мен күнді тігу салты қырғыз халқында да сақталған. Қазақ пен қырғыздың талай асының куәсі болған М. И. Венюков қырғыздар жөнінде: «Буруты хотя тоже ставят на приз пленников и пленниц, но скота жалеют в большом числе» деп жазады [Венюков, 1868, с. 169]. Назар аударарлық жайт, бұл «құл мен күндер» барған жеріне «сіңісіп», уақыт өте келе сол рудың толыққанды мүшесіне айналады. Әрі сол рудың құрамында жеке бір тармағы болып қалыптасады. Қазақтың шежірелік деректерінде жорықта келген бала, ұзатылған қыздың қызметшісі болып келген әйел, бәйгеге тігіліп келген құл мен күң туралы мәліметтер молынан ұшырасады. Тіпті кейбір күңдер мен қызметші әйелдер өзінің ақыл-парасаты арқасында, ел анасы атанып, тұтас бір рудың ұранына айналған. Бұл да көшпелі қоғамның құрылымындағы өзіндік бір ерекшелігі болып табылады. 
Қазақта «өлім бардың малын шашады, жоқтың артын ашады» деген мақала бар. Ас берген адамның тақыр кедейге айналға кездері аз емес. Манас жырында Көкетай ханға ас бергенде ас шығынын тұтас қырғыз халқы көтеріп, жоқшылыққа ұшырап, бұл наразылықты ел билеушілері Манасқа қарсы өз пайдаларына іске асырмақ болады. Қосайдың Манасты кінәлап сөйлейтін кезі:

«От того киргиз обнищал,

Что Манас весь мир угощал,

Все народы оповещал,

На поминках всех величал» [Манас, 2004, с. 32].

Керісінше ас беру барысында малының үстіне мал қосып көбейтіп алған жайттар кездеседі. Бұл ас беруші адамның қоғамдағы рөліне байланысты. Егер ол қолында билігі бар, ел алдында беделді адам болса асқа келуші адамдар «босағаға байлағаным», «әруаққа атағаным» деп үйірімен мал (жылқы) айдап әкеледі. Мысалға ел әңгімелерінде Өскенбайдың асы (1851 ж.) кезінде Ағыбай батыр Құнанбайға «азаға байлағаным» деп 5 құр ат әкелсе, керей Шүршіт бай 10 семіз жылқы бергені айтылады [Тұрсын Жұртбай, URL]. Бұл бір жағы Ағыбайдың Кенесары көтерілісінен кейін қуғындалып, кейін (1849 ж.) кешірім алып, Қарқаралы уезіне қабылданғанының қарымтасы болса керек. Өйткені осы жылдары Құнанбай Қарқаралы уезінің аға сұлтаны болған. Соған қарағанда Құнанбай Ағыбай және оған қарасты шұбыртпалылардың мәселесінің оң шешім табуына қолғабыс еткен болуы тиіс. Осы астағы күресте найман балуанын жеңген құланшы Қоғыл балуан да өзінің сыйынан бас тартып «өз атамның тойында бәйге аламба?!» деп берілген малды «босағаға байлағаным» деп Кұнанбайдың өзіне қалдырып кетеді.
Жалпылама айтқанда ас беру дәстүрінің және онда орын алатын ғұрыптардың қысқаша сипаты осылай болып келеді.

\section{Талдау}

Ас беру дәстүрінің ізін даладағы ескерткіштерден іздесек тас мүсінге келіп тірелеміз. Тас мүсіндердің мәнмағынасы жайлы зерттеушілердің пікірі екіге жарылғаны белгілі. Бірі «тас мүсін марқұмның өзіне арналған» десе, екінші жақ «өлтірген жауының мүсіні» деп қарастырады. Дегенмен зерттеуші ғалымдардың тас мүсінді тұрғызу кезіндегі ас беру (поминки, пиршество) жөнінде ойлары бір жерден шығады. Бірақ археолог ғалымдар бұл тұста асқ̧а жете мән бермеген. Астың (жоғарыда жазғанымыздай) көшпелілерде біржылдан кейін берілетін ғұрыптық рәсім, сондай-ақ үлкен қоғамдық-саяси мәні бар масштабты іс-шара екені тыс қалған. Ал астың өту барысы марқұмға деген еске алу, құрмет көрсету ғана емес, ол жерде қоғамдық мәселелер шешілген. Асқа тек қазақ рулары ғана емес, іргелес елдер өкілдері келетін болған соң, бұл жерде ру аралық даулар, ішкі-сыртқы саясаттағы мәселелер қарастырылған [Кастанье, 1911, c. 92]. Астың қоғамдық-әлеуметтік, саяси маңызы Е. Смағұловтың арнайы диссертациялық жұмысында жақсы көрініс тапқан [Смағұлов, 2005].

Әрине XVIII-XIX ғғ. ас беру дәстүрі мен тас мүсін орнатудың арасында мыңжылдық алшақтықтың жатқаны анық. Дегенмен уақыт алшақтығына қарамастан екеуінің (ас беру мен тас мүсін) арасын жақындастыратын бірнеше өзіндік үндестіктер бар. Бұл үндестіктердің өзін ішкі және сыртқы деп бөлуге болады. Сыртқы - бұл тас мүсін мен астың қоршаған ортасы. Ішкі - 
тас мүсін мен астың өз бойындағы белгілер.

Алдымен сыртқы үндестіктерге тоқталайық. Біріншіден, тас мүсін тұрған жерлер мен ас өтетін орындар жайлау болып табылады. Қазақстан аймағында орналасқан тас мүсіндер барлығы дерлік жайлауларда орын тепкен. Меркі, Жайсаң секілді Шу-Талас аймағында таулы жерлерде орын тепкен тас мүсіндердің орналасуы да осыны көрсетеді [Досымбаева, 2006]. А. Досымбаева тек тас мүсіндерді ғана емес, сонымен бірге жайлау үстінде орын алатын көшпелілердің тұрмыс-салтын өте дәл сипаттаған [Досымбаева, 2006, с. 15].

Тас мүсіндердің барлығы дерлік өзен-су бойларына жақын орналасқан. XIX ғ. орын алған қазақ астарының өткен жерін қарасаңыз жайлаулы жерлерді көресіз. Ә. Марғұлан өз еңбегінде тас мүсіндер тұрған жерлер жайлы: «Халықтың ұлы мерекесі, өлген адамына ас беру, ат шаптыру, балуан күрестіру қашан да сондай жазық алаңда өткізілетін болған» деп жазады [Марғұлан, 2007, 227-б.].

Екінші үндестік, тас мүсіндер орналасқан қоршаудың немесе обаның ішінде адамның жерленбейтіндігі. Яғни ол еске алу ғұрпымен байланысты далада тұрғызылған жәдігер. Ас өтетін орын да осы негіздес. Яғни, ас берілетін адамның зираты ол жерде болуы міндетті емес. Мысалы Абылай ханның сүйегі Қожа Ахмет Ясауи кесенесінде (Түркістанда) жерленгенімен ас берліген жері (1783 ж.) Көкшетау даласы, аға сұлтан Құнанбай Өскенбайға асты Шыңғыстауда емес, Қарқаралы елімен іргелес Көкшеде берді. Кей жағдайда ас марқұмның зираты тұрған жерде де беріледі. Бірақ ол үшін оның зираты жайлауда болуы керек. Қазақ зираттары негізінен қыстаулы жерлерде шоғырланған. Ал күзеу немесе жайлау жерінде тұрған жеке дара мазарлардың атқарушы міндетінен гөрі, саяси маңызы басымырақ. Әдетте бұндай жекелеген зираттар танымал адамның моласы, әрі сол рудың мекендік шекарасын анықтап, әрі айғақ ретінде қызмет атқарып тұрады.

Үшінші үндестік, ас беру мен тас мүсінге тән ортақ ландшафт бар. Ол Сарыарқа үшін өзен-сулы шалғынды кең дала, таулы-қыратты жерлердің арасындағы жазықтар болса, ал Жетісу, Шу-Талас үшін Алатаудың үстіндегі «жазық» жайлаулар (Альпілік шалғындар) болып табылады. Қазақстанның далалы және таулы аймақтарында ас беру дәстүрінің еш өзгешілігі жоқ. Барлығы жайлауда өтеді. Тек ат бәйгесі ғана жер рельефіне байланысты Алатау жотасы секілді таулы жерлерде етектен (тау баурайынан) жоғарыға қарай шаптырылады.

А. Д. Грач Тува жеріндегі тас мүсіндердің тұрақты түрде тау арасындағы ойпаттарда және тау үсті жазықтарында, сонымен қатар негізгі бөлігі өзен алқаптарында орын тепкені туралы жазады [Грач, 1961, с. 15]. Керісінше орманды аймақтарда тас мүсіндердің кездеспейтінін нақтылап көрсетеді. Тек А.Д. Грач өз ойын тас мүсіндерді арнайы күре жолдардың бойына тұрғызған деп қорытады [Грач, 1961, с. 81-82]. Осы тұста А. Д. Грачтың пікіріне еш нұқсан келтірместен тек сәл ғана, яғни «жайлауда» деп түзету енгізуге болады. Тува жерінің этнографиясының маманы емеспін, дегенмен ғалымның сипаттауынан тас мүсіндердің бұл өлкеде де жайлау жерлерде тұрғанын аңғаруға болады. Ал, көшпелі халықтарда ең күре жолдар өтетін жерлер жайлау орындары болып табылады. Өйткені көшпелі рулар жан- 
жаққа тарап кететін қысқы орындармен салыстырғанда жайлауда бір-біріне жақын келіп шоғырлана орналасады. Қысқы уақытта жол қатынасы қиындап, әр ру өз бетімен қалатыны белгілі. Ал жазғы уақытта керісінше, рулар бір-біріне жақын келіп, әрі жолдар ашылып сырт елдерден жолаушылар, елшілер, керуеншілер үздіксіз келе бастайды. XIX ғ. қазақ жерінде жұмыс істеген жәрмеңкелердің уақытын алып қарасаңыз екі мезгілді көресіз. Ол мамыр-маусым айларының және күзгі қыркүйек-қазан айларының аралығы. Бұл көшпелі шаруашылықта көктемгі жабады жүн және күзгі күзем жүн алынатын уақыттар. Әрі күзге таман малдың қоңданған кезі. Осы уақыттарда сырттан саудагерлер көптеп келіп көшпелі рулардың өнімдерін айырбасқа алса, керісінше көшпелілер саудагерден тұрмысына қажетті азық түрлерін, керекті заттарын, сонымен бірге асқа қажетті өзінде жоқ өнімдері, яғни «шай-жемін», «жыртыс» маталарын (теңдерін) алып тұрған. Сондықтан тас мүсін мен күре жолдың жайлауда тоғысуы табиғи түрде қалыптасқан жайт.

Ac беру ғұрпы мен тас мүсіннің арасындағы үндестіктің ең маңызды куәсі, ол - тас мүсін мен ошақ орнының бір алқ̧апта әлі күнге қъабаттаса кездесуі больи табылаdbl. XIX ғ. қазақ астары өткен жерлер мен көне тас мүсіндердің жайлауда қатар келуі жайдан-жай болмаса керек. Сондықтан о баста шығу тегі бір болғандықтан әлі күнге бірбірін толықтырып тұрған далалық дәстүрлер деп айтуға болады.

Қазақстан жерінде тас мүсіндердің жиі кездесетін өлкелердің бірі - Ақтоғай ауданы (Қарағанды обл.). Бұл Ақтоғай ауданы өңірлерінің тас мүсіндері Ж. Құрманқұлов пен
Л. Н. Ермоленконың зерттеулерінде көрініс тапқан [Құрманқұлов, Ермоленко, 2014; Ермоленко, 2004].

2018-2019 жылдары далалық зерттеу жұмыстары барысында Ақтоғай ауданы жерінде бір алқапта орналасқан тас мүсін мен ошақ орындарының бірнешеуін анықтаудың ұшыратудың сәті түсті. Жоғарыда жазғанымыздай, ошақ - далада ас өткен жерлердің атауы. Әдетте ас берілген адамның есімімен аталады.

Орманбет ошавы. Тас мүсін тұрған және ас берген жердің бірі Ақтоғай ауданы Қоңырат ауылдық округіне қарасты Жалаңаш елдімекені маңы. Осы елді-мекеннен солтүстікке қарай 2-3 км қашықтықта, Ақтоғай-Қарағанды тас жолының сол жағында қоршауы бар тас мүсін кейінгі уақытқа дейін сақталып келді. 2009 ж. бұл тас мүсінді белгілеген болатынбыз. Тас мүсін таудың бөктерінде, тас қоршаудың алдында (шығыс бетінде) орналасқан. Қоршаудың ортасы қазылған. Соған қарағанда ОҚАЭ өткен ғасырдың 1960-1970 жж. қазған болуы керек. Бірақ зерттеу материалы бізге белгісіз. Бүгінде бұл тас мүсін Ақтоғайдың мұражайында тұр. Мұражайда осы таудың (Теке) бөктерінен табылған тағы бір тас мүсін қойылған. Соған қарағанда Жалаңаш алқабы көне замандарда талай асты басынан өткерген секілді. Дәл осы жермен байланысты жергілікті халық арасынан XIX ғ. аяқ кезінде (немесе XX ғ. бас кезі) орын алған Орманбеттің асы жайлы мәліметтерді ұшыраттық (III). Ошақ құрылып, қазан асылған жер «Орманбет ошағы» деп аталып кеткен.

«Орманбеттің ошағы» осы Жалаңаш ауылынан шығыста, Жалаңаш өзенінің сол жағында орналасқан. Ал қонақ күтілген киіз үйлердің тігілген жері Жалаңаш 
ауылынан оңтүстікке қарай таудың бөктері болған. Ошақ пен қонақ үй тігілген жердің арасы 3-4 шақырым қашықтықты құрайды. Информатор Мұқажанов Қауаз ақсақалдың айтуынша табақшы жігіттер екі арада тамақты атпен тасып жеткізіп тұрған. Бәйгеге қосылған аттардың жіберілген жері бүгінде Жамшы елдімекені тұрған тұс. Шамамен аттардың өткен қашықтығы 45-50 км болады. Орманбетке ас беруші баласы Нарманбет болған. Нарманбет ауқатты бай, әрі болыс болған адам. Орманбетке ас берген алқаптың ортасында өзінің зираты тұр.

Ербекей ошавы. Екінші бір ac берген орынмен тас мүсіннің қатар келген жері Жамшы ауылдық округіне қарасты Қаратал (бұр. 1 ферма, Калинин) елді-мекені алқабы. Қаратал өзенінің сол жақ қабағында «Ербекей ошағы» деген жер атауы кездеседі (IV). Осы жерде әлтеке Машақ болыстың баласы Ербекейге ас берілген [Аманбаев, 2001, 126-б.]. Машақ әулетінің зираты бұл жерден 30-35 км қашықтықта, Көпбейіт деген жерде бой көтерген.

Ербекей ошағының оңтүстікшығыс жағында, екінші жазықта түркі кезеңінің қоршауы бар тас мүсіні тұр. Тас мүсіннің шығыс жағын ала Жамбыл өзені ағып жатыр. Плита тастардан қойылған қоршау екі бөліктен тұрады. Тек біреуінің (шығыс) алдында тас мүсін сақталған.

\section{Шегетай ошавы. Шегетай} ошағы Жамшы ауылдық оругіне қарасты Жалаңтөс ауылынан (бұр. 2 ферма, Бірлестік) оңтүстікке қарай 5-6 км қашықтықта орналасқан. Шегетай XVIII ғ. өмір сүрген Жалаңтөс батырдың ұрпағы болып келеді. Информатор Қ. Сәденовтың мәліметінше XIX ғ. соңында осы жерде Мұса мен Мұстафа әкелері
Шегетайға ас берген (V). Мұса - би болған адам. Осы Шегетай ошағы орналасқан төңірек тас мүсіндердің ең бір шоғырланған жері болып табылады. Жергілікті тұрғындардың айтуынша өткен ғасырдың 70-нші жылдарына дейін Жалаңтөс ауылы тұрған жердің өзінде 6-7 тас мүсін болған. Көбін кейін «мұражайға» деп сыртқа алып кеткен. Қыстақтар ашылып, мал қоралары салынған кезде «іргетасқа» жаратылып кеткендері де болған. Содан бүгінде бір ғана тас мүсін қалған болуы тиіс. Шегетай ошағының жанында тағы бір тас мүсін соңғы уақытқа дейін сақталып келген. Осыдан «6-7 жыл бұрын бұл тас мүсінді Ақтоғайға мұражайға алып кетті» дейді Теректі қыстағының иесі Қайыркен деген кісі.

Ақтоғай ауданы тас мүсіндерінің бірқатарының XIX ғ. ас беру орындарымен қатар келуі бұл екі ғұрыптың ерте кездерде біртұтас шара болғанын дәлелдейді. Тас мүсін тұрған жерлердің атаулары соңғы ас арналған адаммен байланысты (Орманбет ошағы, Ербекей ошағы, Шегетай ошағы) сақталып қалған. Ал, кезінде алқаптың дәл осы тас мүсін иесінің құрметіне «бәленнің ошағы» деп бірнеше жүз жыл аталғаны, меніңше еш күмән тудырмайды. Сондықтан бұндай жерлердің атаулары келесі өткен аспен байланысты кезектесіп ауысып отырған. Немесе қанша ас берілсе де алдыңғы адамның даңқы кейінгі адамның есімдеріне жол бермеген (немесе керісінше). Мысалы, жергілікті ел арасында асқа қатысты болмаса да, мазар тұрғызуға байланысты келесідей әңгіме бар. XVIII ғ. өмір сүрген Жидебай батыр (қаракесекәлтеке) дүниеден өтер алдында өзін «Мәшүріп басына» жерлеуді өсиет етеді. Маңайында отырғандар: «ол жерде Мәшүріптің моласы тұр, сіздің 
атыңыз аталмай қалады ғой» дейді. Сонда Жидебай батыр: «мен барғанда Мәшүріп артын қысады» депті. Шыныменде бүгінде ол жер «Жидебай басы» аталады (Қарағанды обл., Шет ауд.). Жидебай батырдың мазарынан әріректе сәулеті жағынан асып түспесе, кем түспейтін Мәшүріптің моласы тұр. Мәшүріпті «Байшора» деп те атайды.

Енді тас мүсін мен астың ішкі, яғни бойындағы үндестіктеріне келейік. Тас мүсіннің бойындағы тұрақты көрініс қолында ыдыс ұстап тұрады. Ыдыстар пішініне қарай кесе, тоставан, құты тәріздес болып келеді. Ыдыстардың барлығы сұйық тағамдарға арналған. Бұл ыдыстың мән-мағынасы жөнінде әр түрлі пікірлер бар, дегенмен зерттеушілердің ойлары үндес келеді. Көпшілігі оның қымыз секілді сүт тағамына арналғанына тоқталады. Зерттеушілердің бірқатары көшпелі халықтардың (негізінен алтай, сібір халықтарының) әдет-ғұрпымен салыстыра келе, бұл жердегі көріністі - «айналма» кесе рәсімі (обряд «круговой» чаши) деп қарастырған [Ермоленко, 2004, с. 62]. Я.А. Шер Л.Р. Қызыласовтың пікірін құптап: «Таким образом, кубок, который изображен в правой руке, есть не что иное, как знак присутствия, участия самого покойного в устроенном в его честь пире» деп жазады [Шер, 1966, c. 58].

Егер осы ыдыстың мәніне кеңірек тоқталатын болсақ, онда қайтадан қазақтың ас беру дәстүріне ораламыз. Асқа келген қонақтардың барлығы өздерімен сабаға артылған қымыз ала келетін болған. Асқа тобымен келе жатқан ру өкілдерінің арасындағы міндетті көрініс, ол түйе жегіліп, қос дөңгелекті арбаға артылған үлкен саба болады. Не- месе сабаны арбасыз, түйенің өзіне теңдеп әкеледі. Тіпті жаяу, жалпылап келген жекелген адамның өзі қолына торсық қымызын ұстай келеді (соңғы мәліметті автор 2003-2004 жылдары Моңғолиядағы қазақ этникалық тобының арасында куә болған жайттарынан мысалға алып отыр). Бұл жердегі, яғни қымыз ала келудегі мақсат асқа көмек емес, негізгі мағына қайтқан адамға, яғни аруаққа арнауы (тие берсін) болса керек. Тас мүсіннің қолына ыдысұстап тұрғанын ескерсек, асқа келушілердің «тие берсін» деп саба толы қымыз әкелудің түйісетін ортақ суреті шығады. Бұл тұста Л. Н. Ермоленконың ыдысты түркімоңғол халықтарында қымыз құйу садақасымен байланыстырғаны дәл айтылған [Ермоленко, 2004, с. 61].

Асқа шақырудың негізгі атауы «сауын айтудың» мән-мағынасы осы ыдыспен үндес келеді. Қазақта сауылатын төрт түлікті «сауын мал» (мыс.: сауын бие, сауын сиыр) деп атайды. Ас жағдайында сауын айту тікелей қымызды білдіреді. Яғни, «сауын айту» бір жағы асқа шақыру болса, екінші мағынасы сауын айту арқылы асқа шақырылған адамның қымыз ала келуін міндеттейтін жазылмаған дала заңы болса керек. Cipə, көне дәуірлерде асқа келген әрбір ру өкілдері марқұмның бейнесі қашалған тасқа келіп «батасын» жасап, тас қоршаудың ішіне «тие берсін» деп әкелген қымызынан (белгілі бір мөлшерде) төгу рәсімдері орындалған шығар. Астарда саба-саба қымыз беріліп, астау-астау еттің тартылуы осы марқұмның ырзашылығы үшін жұмсалады. Қазақтың «өлі разы болмай тірі байымайды» деген мақалы осы ескілікті далалық түсінік негізінде қалыптасқан.

Әрине астың бәрі бейбіт өте бермейді. Кейде әдейі келіп астың 
шырқын бұзатын жағдайлар болады, немесе керісінше ас иесі келген қонақты ел алдында кемсітетін оқиғалар орын алады. Соңғы жағдайда намысы тапталған қонақ асқа деп әкелген қымыз ақтарып, жерге төгіп кететін болған. Мысалы Қобыланды жырында (тек бұл жерде ас емес той айтылады) Алшағырдың тойына барған кезде Қыдырбайды «баласы жоқ» деп кемсітіп жібергенін еске түсіретін кезі:

«Алшағырдың тойында,

Жиренқопа бойында,

Қара нарыңды құшақтап,

Қара сабаңды пышақтап,

Қайтқаның бар ма ойыңда» деген жерлер осындай оқиғаның көріністері.

Қазақта қаралы шаңыраққа «әруаққа атағаным» деп мал әкеліп байлайды. Немесе қайтқан адамға сойылған малды бауыздағанда, немесе етінен дәм татқанда «тие берсін» деп айтады. Бұл жайт Ш. Уәлиханов жазып алған «Өлі мен тірінің достығы» деген ертегіде жақсы көрініс табады. Онда тірі досы өлген досының өтініші бойынша оның жауын, жауының әйелін, екі қызын, астындағы атын, тіпті иті мен сұңқарына дейін өлтіреді. Өлтірер алдында «досыма тие берсін» деп шабады [Валиханов, 1985, с. 63]. Артынан тірі досы келгенде бұлардың барлығы өлі досына қызмет етіп жүргенін көреді. Ш. Уәлиханов қазақтардың аруаққа мал шалуы жайлы: «Такие жертвы они называют курбандык и садака и эти некоторым образом смягчают их языческое значение» деп жазады [Валиханов, 1985, c. 56].

Тас мүсіндердің қолында ыдыс қана емес, кейбірінде аяқ жағында табақтың суреттері қашалған. Соның бірін Қозы Көрпеш - Баян сұлу дыңының ішіндегі (бүгінде жоқ) тас мүсіндердің бірінен көреміз. Осы дыңның ішінде тұған тас мүсіндердің (әйел адамдар) бірінің қолында ыдыс қана емес, сонымен қатар алдында ет салынатын аяқты астау қойылған [Кастанье, 1910. PL XIV, рис. 14]. Бұл жайттың барлығы далалық түсінікте марқұмдардың тіріден тағам дәмететінін анық көрсетеді. XIX ғ. 80-нші жылдары Жетісуда зерттеу жұмыстарын жүргізген Н. Л. Зеландтың мына бір мәліметі назар аударарлық. Ол: «в Иссыгатинском ущелье Токмакского уезда есть большой камень с изображением человеческой фигуры неизвестного происхождения. Этот камень каждый проезжающий киргиз считает нужным промазать салом» деп жазады [Зеланд, 1885, с. 32]. Абакан жерінде тас мүсінмен байланысты дәл осындай салтты Д. Мессершмидт (1722 ж.) кездестірген. Ол Қара және Ақ Юс тауындағы «Козан-Куш таш» мүсінін сипаттап, татарлардың бұл тасты құрметтеп, өзінің жолазықтарынан тамақ қалдыратыны жайлы жазады. Тоқымақ сайындағы тас мүсін секілді бұл ескерткіштің де еріндері маймен сыланған. Бұл жөнінде Д. Мессершмидт: «рот ее также весь был вымазан жиром или маслом и блестел на солнце так, как будто был покрыт лаком» деп жазады [Радлов, 1989, с. 433].

Қазақта жол үстінде белгілі немесе әулие адамның тұсынан (моласынан) тоқтамай өтпейтін салт бар. Яғни, бұндай жерде сәл аялдайды немесе aт шалдырып (аттың, белін суыту) алады. Ал, жорық үстінде немесе тым асығыс болғанда бір аяzын үзензгіден шыzару секілді ырымын жасап өтетін болған. Бүгінде бұл ырымға сенетін адамдар көлік жағдайында бір қолын рөлден алып өтеді (автордың Ұлытау ауданынан жинаған мәліметтері). Бұдан шығатыны (негізінен Д. Мес- 
сершмидт пен Н. Л. Зеландтың дерегінен) көне дәуірлерде тас мүсіндер жолай ұшырасқан адамдар үшін кідіріс жасап, жол азығынан «садақа» қылатын киелі орындар болғаны аңдалады. Шыңғыстауда белгілі Қоңыр әулие үңгірі бар. Осы үңгірдің алдында XIX ғ. әйел адамның тас мүсіні тұрған. Бұл тас мүсін де жергілікті қазақтардың құрбандық шалып, ырымдарын жасайтын орны болған. Бұл туралы деректе: «КонурАулие - святая пещера киргизов (казахов - О.О.) близ Семипалатинска, куда стекаются массы народа для поклонения статуе в человеческий рост, изображающей женщину. Кругом находять мелкие вешицы из камней, бусы, бронзовая статуетки; вокруг горы, в которой находятся Конур-Аулие, совершают жертвоприношения; сюда пригоняется и скот в случае болезни» [Конур-Аулие, 1892].

Деректерде ас кезінде асылған еттен және басқа да дәмнен алып қабірдың ішіне тастайтыны жайлы мәліметтер кездеседі. Мысалға, И.А. Кастанье: «Так напр. князь Эристов, говоря о поминках в памяти хана Абулхаира бывшего некогда султаном киргиз Малой Орды, пишет что при совершении ежегодной тризны копье, находившееся на памятнике, вынималось, в ямку клали снеди и мяса, вешались новые лоскутья и копье ставилось опять на свое место» деп жазады [Кастанье, 1911, с. 91]. 1771 ж. осы жермен өткен Н. Рычков Әбілқайыр ханның мазарының алдында арнайы тұрғызылған төртбұрышты тас қоршау жайлы жазады. Оның сипаттауынша ас күні бұл қоршаудың ішінде құрбандық шалынған [Дневные записки, 1772, с. 45].

Жалпы моланың басына ту қадау жаугершілік уақыттың көрінісі болса керек. Өйткені моланың басы- на ту немесе сырық (сынық найза, бақан) қадау XIX ғ. деректерде сирек кездеседі. Керісінше Н. Рычковтың күнделік жазбаларын оқып отырсаңыз қазақ даласы XVIII ғ. (қазақ-қалмақ шайқасының кезеңі) осындай сырық қадалған оба, молаларға толы сияқты әсерде боласыз.

Қазақта тас мүсінмен байланысты мәліметтердің ішінде «Қозы Көрпеш - Баян сұлу» жыры ерекшеленеді. Екі ғашықтың оқиғасы, олардың «моласына» тұрғызылған дың ғимараты, ішіндегі тас мүсіндер қазақ халқында үлкен жырға айналған. Халықтың айтуында дың ішінде болған әйел мүсіндері Баянның құрбылары Таңсық, Айғыздың мүсіндері. Бұл жерде Айғызбен Таңсықтың мүсіндерін жоқтау айтып тұрған бейне ретінде түсіндіріледі. С. Б. Броневский бұл тас мүсіндер жөнінде: «Киргизцы почитают сии статуи за некоторых добродетельных людей, волшебством превращенных в камень, почему и боготворят их, делая жертвоприношения по своему обычаю» деп жазады [Броневский, 1830, c. 72].

Көне сақ обаларынан шығатын ыдыстар, малдың сүйектері мәйітті жерлеумен оны жөнелтудің ғұрыпы аяқталмайтынын дәлелдей түседі. Бұл жора-жосын оның жылы өтіп, асы берілгенге дейін жалғасады. Кейбір сақ обаларында кездесетін дромостар (дәліз) қабірге сырттан белгілгі бір уақытқа дейін қатынас болып тұрғанын көрсетеді.

Тас мүсін зерттеуші ғалымдардың арасында кеңіне танымал деректердің бірі - көне қытай жылнамалары (Синь-Таншу, Чжоушу, Суйшу және т.б.). Бұл жылнамаларда көне түріктердің өзінің белгілі адамдарына тас мүсін орнату дәстүрі нақтылы сипатталған. Тіпті кей жағдайларда 
көшпелілердің билеушісі қайтыс болуына байланысты қытайлық делегация өкілдері асқа қатысып, өз тараптарынан көшпелілерше марқұмға құрбандық шалып, храм тұрғызып, қабырғаларына ерліктерін жазып, тіпті тас мүсінін қашауға дейінгі ісәрекеттерге барады. Соның жарқын бір көрінісі Тоныкөк пен Білге қағанның ескерткіштері. Бұларды тұрғызуда қытайлық шеберлер тікелей атсалысқаны белгілі. Әрі бұл делегацияны мемлекет шенеуіктері бастап келіп, императордың атынан қайғыға ортақтастығын, сәлемін жеткізіп отырды. Назар аударарлық жайт бұл дәстүрді қытайдың билеуші династиялары XIX ғ. бас кезіне дейін сақтап келді.

Іргелес болғандықтан Қытай елі ғасырлар бойы көшпелілермен саяси бақталастықта, алма-кезек үстемдік, соғыс немесе бейбіт келісім негізінде өмір сүрді. Қытай солтүстік және солтүстік-батысындағы көшпелілерді үнемі назарында ұстап, олардың саяси өміріне араласып «хан сайлау», сондай-ақ билеушінің өмірден өтуіне байланысты аза тұту (ас беру) шараларында шебер дипломатиялық қадамдар жасай білді. Мысалы VIII ғ. Төнікөк пен Білге қағанның қайтыс болуына байланысты Тан империясы өзінің әскер басшысы мен мемлекет қызметшілері бастаған арнайы делегациясын жіберіп көңіл айтса, ал XVIII ғ. қазақ хандары Абылай мен Әбілфейіз қайтыс болғанда осы жайт қайталанады. Екі дәуірде де қытай делегациясы билеушілердің жылдық асына келеді. Тек соңғысында құрылыстар орын алмайды. Абылай мен Әбілфейізде Цинь империясының делегациясы өз есептерінен арнайы ac өткізеді. Мысалы Әбілфейіз хан үшін олар жергілікті қазақтардан 50 жылқы, 50 өгіз, 100 қой сатып алып асқа сойысқа береді. Деректе Циндіктердің Әбілфейіз ханды жоқтауы келесідей сипатталады: «Затем поставлены были на четыре угла длинныя жерди и от них протянуты веревки; а к веревкам прицеплены были несколько длинных листов, вычерненной тонкой бумаги; и когда все было готово, то Амбо и все бывшие с ним, стали вокруг сего четвероугольника, бумага по данному знаку была зажжена и все предстоящие тут захватя свои лица, казалось, горько заплакали» [Киргиз-кайсаки, 1820, с. 123124]. Циндіктердің төрт бұрышқа қазық қағып, арасын арқанмен белдеулеп шығуы тас мүсіннің артындағы төрт бұрышты тас қоршауын еске түсіреді. Абылай туралы мәліметтер де осы деректе айтылады. Онда: «Таковая же почесть воздана была другим Китайским Амбою, умершему в 1781 году Аблай султану. Он прислан был также по прошествии одного года после смерти Аблая и с таким же числом людей» деп жазылады [Киргизкайсаки, 1820, с. 124].

Міне, осы мың жыл бойы өзгерісіз жеткен қытайлық дипломатиядан көшпелілердің ас беру дәстүрінің қаншалықты маңызды ғұрып, әрі астарында үлкен саяси мән-мағына жатқан қоғамдық шара екеніне көз жеткізуге болады. Сонымен бірге бұл жылнамалар ескі дәуірлерде ас беру кезінде орын алған тас мүсін қою дәстүрінің, тек кейін келе ығысып шыққанын көрсетеді.

Түркі қағанаты кезінде ас берудің жарқын бір көрінісі Манас жырындағы «Көкетайдың асы» болып табылады. Ал осы жырдағы аталатын айтулы ерлердің қайсысын алып қарасаңызда далада мүсін тұрғызуға лайық тұлғалар.

Мына жайтты да естен шығармаған жөн. XVIII-XIX ғғ. астар 
туралы мәліметтер тек ер адамдармен байланысты. Әйел адамға ас беру туралы еш дерек кездеспейді. Ал түркі дәуірінің тас мүсіндердің арасында әйел адамның бейнесі жиі, тіпті сиректе болса бала бейнесі кездеседі. Әйел адамдарға ас бермеу кейін ислам әсері негізінде болуы мүмкін. Көшпелі халықтарда әйел адамның рөлі қоғамда үлкен ықпалға ие болғаны белігілі. Қазақ даласында сақталған сәулет ескерткіштерінің көпшілгі, әрі сақталып тұрғаны әйел адамдармен байланысты. Мысалы: Айша бибі, Бабаджа хатун, Болған ана, Жұбан (Жуан) ана, Белең ана, Бегім ана және т.б. мазар-кесенелер. Қазақта тұтас бір ру атына немесе ұранға айналған ел аналары жетерлік.

\section{Түйін}

Тас мүсіндердің ығысып шығуы тек ислам дінінің таралуымен байланысты болмаса керек. Өйткені ортағасырда ислам діні жете қоймаған аймақтардың өзінде тас мүсін қою дәстүрі жоғала бастайды. Жалпы тас мүсін қою дәстүрі Еуразия далалы аймақтарының барлығында бірдей тоқырауға ұшырайды. Моңғол даласындағы тас мүсіндердің, сына жазуларының түркі қағанаты кезеңінің, оның ішінде олардың билеушілері және т.б. тарихи тұлғаларымен байланысты екендігі белгілі. Соған қарағанда бұл дәстүрдің ығысып шығуының бір шеті Шыңғыс хан құрған Моңғол империясының саясатында жатуы мүмкін. Сірә, моңғол билеушілері өздері алмастырған түркілік биліктің бұл дәстүріне қырын қараған болуы керек. Ал, ислам дінінің қанат жайуы қазақ даласында тас мүсін орнатуды мүлде тоқтатты. Сондықтан бұл әдет-ғұрыптың тек исламмен қайшы келмейтін тұстары ғана қалды.

Қазақтың тұрмысында жиі кездесетін жайт, өлер алдында «құлағыма ат дүбірі келіп жатсын», «суатқа жақын қойындар, жылқының тұяғының дыбысын естіп жатайын» деп өзін суға жақын жерлеуді аманат етуі секілді мәліметтер аста ат шаптыру салтының бір түсіндірмесі. Яғни, далалық түсінікше марқұмның құлағына «жетіп жатқан» ат тұяғының дүбірі оның ұрпағының марқұмға қаншалықты «ас та - төк» жиын өткізіп жатқанының куәсі деуге де болады. Бұл салт-жоралғылардың барлығын сол көшпелі мәдени орта қалыптастырған түсініктер.

Тас мүсіндерді уақыты, орналасқан өлкесі, орындалу тәсілі, бейнеленуі және т.б. ерекшеліктеріне қарамастан барлығына тән ортақ бір жайт бар. Ол - көшпелі мәдениет ортасы қалыптастырған ата-бабалар рухы. Оларды еске алу мен жөнелту осы ас беру мен тас мүсін орнату дәстүрін туғызды.

\section{ИНФОРМАТОРЛАР:}

I. Наурызбаев Әлім. 1930 ж.т. Қарағанды облысы, Ұлытау ауданы, Бозтұмсық ауылы. ЖАЭ-1997.

II. Орынбаев Рашид. 1928 ж.т. Қарағанды облысы, Ұлытау ауданы, Сарылық ауылы. ЖАЭ-1997.

III. Мұқажанов Қауаз. 1937 ж.т. Қарағанды қаласы. Зейнеткер (қызмет еткен жері: Қарағанды облысы, облысы Ақтоғай ауданы). САЭ-2018. 
IV. Бәкірова Рузия. 1949 ж.т. Зейнеткер. Қарағанды облысы, Ақоғай ауданы, Нүркен (Жамшы) ауылы. САЭ-2018.

V. Сәденов Қуандық. 1961 ж.т. Балқаш қаласы тұрғыны. Туып өскен жері Ақтоғай ауданы, Жамшы кеңшары Бірлестік ауылы. САЭ-2019.

\section{ӘДЕБИЕТ}

1. Ақжолтай Ағыбай батыр. Жезқазған: Облтипография, 1992. 180 б.

2. Аманбаев Зияда. Әулет аралық естелік. Естелік-шежіре. 1-бөлім. Балқаш: Қалалық баспахана, 2001. 160-бет.

3. Әбімев X. Аспан сыры. Алматы: Қазақ мем-тік саяси әдебиет баспасы, 1962. 2516 .

4. Броневский С.Б. Записки генерал-майора Броневского о киргиз-кайсаках Средней орды // Отечественные записки. 1830. Ч. 43. № 124. С. 119-356.

5. Валиханов Ч.Ч. Следы шаманства у киргизов // Собрание сочинений в пяти томах. Т. 4. Алма-Ата: Гл. Ред. Каз. Сов. Энцикл., 1985. 463 с.

6. Венюков М.И. Путешествие по окраинам русской Азии и записки о них. СПб: Типография Императорской Академии наук, 1868. 528 с.

7. Грач А.Д. Древнетюркские изваяния Тувы. М.: Изд-во вост. лит., 1961.96 с.

8. Дневные записки путешествия капитана Н. Рычкова в Киргис-кайсацкой степи 1771 году. СПб.: Типография Императорской Академии наук, 1772. 105 с.

9. Досымбаева А. Западный Тюркский каганат. Культурное наследие казахских степей. Алматы: Типография Комплекс, 2006. 168 с.

10. Ермоленко Л.Н. Средневековые каменные изваяния Казахстанских степей (типология, семантика в аспекте военной идеологии и традиционного мировоззрения). Новосибирск: Изд-во ИАЭт СО РАН, 2004. 132 с.

11. Зеланд Л.Н. Киргизы (этнологический очерк) // Записки Западно-сибирского отдела РГО. 1885. Кн. 7, вып. 2. С. 1-78.

12. Кастанье И.А. Древности Киргизской степи и Оренбургского края // Труды ОУАК. 1910. Вып. 22. 332 с.

13. Кастанье И.А. Надгробная сооружения киргизских степей // Труды ОУАК. 1911. Вып. 26. 102 с.

14. Киргиз-кайсаки Большой, Средней и Малой орды по записям Андреева, с дополнениями П.К. Фролова и издателя // Сибирский вестник. 1820. Ч. IX-XI. 183 с.

15. Конур-Аулие // Витебская Губернская Ведомости. 1892. № 63.

16. Кызласов Л.Р. О назначении древнетюркских каменных изваяний, изображающих людей // СА. 1964. № 2. С. 27-39.

17. Құрманқұлов Ж., Ермоленко Л. Ежелгі Сарыарқа тас мүсіндер (каз., орыс, ағыл. тілд.). Қарағанды: «Credos Ltd C», 2014. 168 б.

18. Левшин А.И. Описание киргиз-казачьих, или киргиз-кайсацких орд и степей. Ч. 3: Этнографические известия. СПб.: Типография Карла Края, 1832. 304 с.

19. Манас: Великий поход. Кыргызский эпос / Пер. С. Липкина и др. Бишкек: Шам, 2004. 404 c.

20. Марұұлан Ә.Х. Ежелгі жыр, аңыздар: Ғылыми-зерттеу мақалалар. Алматы: «Жазушы», 1985. 368 б.

21. Марвұлан Ә. Ұлытау төңірегіндегі тас мүсіндер // Ә.Х. Марғұлан шығармалары. Алматы: «Алатау», 2007. IV т. 221-274-бб.

22. Народы России. Киргизы: [этнографические очерки]. СПб.: «Досуг и дело», $1880.58 \mathrm{c}$.

23. Радлов В.В. Из Сибири (страницы дневника) / Пер. с нем. К.Д. Цивиной и В.Е. Чистовой. Прим. и послесл. С.И. Вайнштейна. М.: Наука, 1989. 749 с. 
24. Руденко С.И. Культура населения Горного Алтая в скифское время. М.-Л: Изд-во АН СССР, 1953. 402 с.

25. Смавұлов E.M. Қазақтың ас беру дәстүрі: қоғамдық-әлеуметтік қызметі (XVIII-XIX ғғ. деректер бойынша): тарих ғыл. канд. ... дис. автореф. Алматы, 2005. 33 б.

26. Тұрсын Жұртбай. Құнанбай (Жәбір сұлтаны) // Абай әлемі (ұлы ойшылдың өмірі мен шығармашылығына арналған онлайн-эниклопедия). URL: https: // abaialemi. $\mathrm{kz} / \mathrm{post} /$ view?id=910

27. Халид Құрбанвали. Қазақта мәйіт шығару // Тауарих хамса: (Бес тарих). ауд. Б. Төтенаев, А. Жолдасов. Алматы: «Қазақстан», 1992. 304 б.

28. Чорманов М. Казахские народные обычаи. Караганда: «Арко», 2000. 104 с.

29. Шарипов С. Бағаналы елінің жайы // Шығармалар жинағы. II т. Алматы: «Жазушы», 1982. 508 б.

30. Шер Я.А. Каменные изваяния Семиречья. М.-Л.: Наука, 1966. 141 с.

31. Шомбал-Кукашев Р. О символике старинного казахского поминального ритуала «түйе шешу» // Қазақтың әдет-ғұрыптары мен салт-дәстүрлері: өткендегісі және бүгіні. Алматы: Ғылым, 2001. С. 351-373.

\section{REFERENCES} Kazakh).

1. Aqjoltay Agybay batur (Lucky Agybai batyr). 1992. Jezkazgan: Obltipografiya (in

2. Amanbayev, Z. 2001. Äwlet araliq estelik. Estelik-şejire (Genealogy memo). 1-bölim. Balqaş: Qalalyq baspaxana (in Kazakh).

3. Abishev, H. 1962. Aspan siri (Mystery sky). Almaty: Kazakh mem-tik sayasy baspasy (in Kazakh).

4. Bronevskiy, S. B. 1830. In: Otechestvennyye zapiski (Domestic notes), 43, no. 124, 119-356 (in Russian).

5. Walikhanov, Sh. 1985. In: Sobraniye sochineniy: v pyati tomakh (Collected works in five volumes). Vol. 5. Alma-Ata: Glavnaya Red. Kaz. Sovet. Entsiklopedii (in Russian).

6. Venyukov, M. I. 1868. Puteshestviye po okrainam russkoy Azii i zapiski o nikh (Travel to the outskirts of Russian Asia and notes about them). Saint Petersburg: Tipografiya Imperatorskoy Akademii nauk (in Russian).

7. Grach, A. D. 1961. Drevnetyurkskiye izvayaniya Tuvy (Turkic sculptures of Tuva). Moscow: Izd-vo vost. lit-ry (in Russian).

8. Dnevnyye zapiski puteshestviya kapitana N. Rychkova v Kirgis-kaysatskoy stepi 1771 godu (Day notes of the voyage of captain N. Rychkov in the Kirgis-Kaisak steppe in 1771). 1772. Saint Petersburg: Tipografiya Imperatorskoy Akademii nauk (in Russian).

9. Dosymbayeva, A. 2006. Zapadnyy Tyurkskiy kaganat. Kulturnoye naslediye kazakhskikh stepey (Western Turkic Kaganate. Cultural heritage of the Kazakh steppes). Almaty: "Kompleks" Publ. (in Russian).

10. Yermolenko, L. N. 2004. Srednevekovyye kamennyye izvayaniya Kazakhstanskikh stepey (Middle-century stone sculptures of Kazakhstan steppes). Novosibirsk: Archeology and ethnography Institute SB RAS (in Russian).

11. Zeland, L. N. 1885. In: Zapiskiy zapadno-sibirskogo otdela Russ. Geogr. Obshch (Zapiskiy of the West Siberian Department of Russ. Geogr. Society), 7, 2, 1-78 (in Russian).

12. Kastaniye, I. A. 1910. In: Trudy Orenburgskoy Uchenoy Arkhivnoy Komissii (Proceedings of the Orenburg Scientific Archival Commission), 22 (in Russian).

13. Kastaniye, I. A. 1911. In: Trudy Orenburgskoy Uchenoy Arkhivnoy Komissii (Proceedings of the Orenburg Scientific Archival Commission), 26 (in Russian). 
14. Kirgiz-kaysaki Bolshoy, Sredney $i$ Maloy ordy po zapisyam Andreyeva, s dopolneniyami P.K. Frolova i izdatelya (Kirghiz-kaisaks of the Great, Middle and Small Horde according to Andreev's notes, with additions by P.K. Frolov and the publisher). 1820 / Sibirskiy vestnik, IX-XI (in Russian).

15. Konur-Auliye. 1892. In: Vitebskaya Gubernskaya Vedomosti (Vitebsk Provincial Gazette), no. 63 (in Russian).

16. Kyzlasov, L. R. 1964. In: Sovetskaya arkheologiya (Soviet archeology), 2, 27-39 (in Russian).

17. Kurmankulov, J., Ermolenko, L. 2014. Ejelgi Saryarqa tas müsinder (Ancient Saryarka stone sculptures). Karagandy: "Credos Ltd C" (in Kazakh, Russian, English).

18. Levshin, A. I. 1832. Opisaniye kirgiz-kazachiikh, ili kirgiz-kaysatskikh ord i stepey (Description of Kirghiz-Cossack or Kirghiz-kaisak Orda). Ch. 3: Etnograficheskiye izvestiya, Saint Petersburg: "Karl Kray" Publ. (in Russian).

19. Manas: Velikiy pokhod. Kyrgyzskiy epos (Manas: the Great campaign. Kyrgyz epic). 2004. / Per. S. Lipkina i dr. Bishkek: "Sham" (in Russian).

20. Margulan, A. X. 1985. Ejelgi jyr, anyzdar: gylymi-zertteu makalalar (Ancient poems, legends: Research articles). Almaty: "Jazushi” (in Kazakh).

21. Margulan, A. 2007. In: A.X. Margulan shygarmalary. Almaty: “Alatau”, vol. IV, 221-274 (in Kazakh).

22. Narody Rossii. Kirgizy: [etnograficheskiye ocherki] (People of Russia. Kirghiz: ethnographic essays). 1880. Saint Peterburg: "Dosug i delo" Publ. (in Russian).

23. Radlov, V. V. 1989. Iz Sibiri. Stranitsy dnevnika (From Siberia. Diary pages) / Per. s nem. K.D. Tsivinoy, V.Ye. Chistovoy. Prim. i posles. S.I. Vaynshteyna. Moscow: "Nauka" Publ. (in Russian).

24. Rudenko, S. I. 1953. Kultura naseleniya Gornogo Altaya v skifskoye vremya (Culture of the population of the Altay Mountains in the Scythian period). Moscow-Leningrad: Izd-vo AN SSSR (in Russian).

25. Smagulov, E. M. 2005. Kazakhtyn as beru dasturi: kogamdik-aleumettik kyzmeti (Trizna-Kazakh tradition): thesis Cand. hist. sciences. Almaty (in Kazakh).

26. Tursyn Jurtbay. URL: https: // abaialemi.kz /post/ view?id=910 (in Kazakh).

27. Halid Kurbangali. 1992. Tauarih hamsa: Bes tarih (Tauarikh hamsa: Five stories) / awd. B. Totenayev, A. Joldasov. Almaty: "Kazakhstan" (in Kazakh).

28. Chormanov, M. 2000. Kazakhskiye narodnyye obychai (Kazakh folk customs). Karaganda: "Arko" Publ. (in Russian).

29. Sharipov, S. 1982. Baganaly elinin jayi (The situation in the country of Baganaly) / Shygarmalar jinagy. II t. Almaty: "Jazushi” (in Kazakh).

30. Sher, Ya. A. 1966. Kamennyye izvayaniya Semirechiya (Stone sculptures of Semirechye). Moscow-Leningrad: "Nauka" Publ. (in Russian).

31. Shombal-Kukashev, R. 2001. In: Kazakhtyn adet-guriptari men salt-dasturleri: otkendegisi jane bugini (Kazakh customs and traditions: past and present). Almaty: "Gylym" Publ., 351-373 (in Russian, Kazakh). 